\title{
Challenges of Business in Poland in Old and New EU Policy Fields: Analytical Approach
}

\author{
Jarosław Filip Czub \\ University of Warsaw, Warsaw, Poland
}

\begin{abstract}
The aim of the article is to analyze the challenges of developing business in Poland in old and new EU policy fields. For the last two decades, Polish policy of business operations has been implemented at a national level largely on the basis of the aims pursued by the European Union, which influence the modernization of the state in regards to economic progress, infrastructure development and technological advancement. Such provisions were included, for instance, in the new and last cohesion policy prospect for the period of 2014-2020. One of the goals of this article is to present a model of functioning and development of business in Poland, taking into account the strategies of the European Union in the period 2014-2020. In this article I made attempts to answer the following questions: What is the level of impact exerted upon Polish business by new policies introduced by the EU? Is the introduction of new EU policies significant for the development of business in Poland? Or does it cause its partial destruction that impedes the development of companies, especially small- and medium-sized enterprises, which significantly contribute to the increase and development of GDP in Poland and in most member states of the EU? Is the functioning of business in Poland dependent on new EU policies and new legal regulations introduced by decision-makers at the national level?
\end{abstract}

Keywords: Business, lobbying, European Union, Poland, EU policy

\section{Theoretical and Methodological Aspects}

Considering the methods used by various national and foreign subjects to conduct business in Poland, we may formulate the following research hypothesis: At a national level and within various areas of policies, Polish business is not being developed sufficiently. Not all aspects related to operating business in Poland by particular subjects are taken into account in decision-making and legislative processes aimed at the facilitation of operating business in Poland. This is due to the deficit or lack of legal acts suitable for Polish business and due to changes made by particular Polish policy-makers for the purpose of development of business in Poland, especially in the area of micro-, small- and medium-sized enterprises. Improvement in harmonization of law with new policies established by the EU in regards to the member states, Poland included, constitutes another important element. Despite all negative aspects that prove the insufficient efficiency of Polish business functioning at a high level, I will also try to present positive elements of influence on conducting business in Poland, taking into account the introduction of new European policies (Traktat o Unii Europejskiej, http://europa.eu, http://www.eba.europa.eu).

The key research method employed to verify the thesis formulated above is based on the systems and 
microsystems analysis, which make it possible to study the functioning of Polish business within the system of new policies and guidelines of the EU, which in great measure impose the business model not only on Poland, but on all 27 member states of the EU as well. The systems analysis can be used to create a model of the direction of business development within the Polish institutional system. In particular, it will allow for the presentation of the specificity of business, including the role it plays in the economic system of Poland. Within the systems analysis the microsystems analysis may be performed to study the opinions expressed by government experts and decision-making subjects that influence the development of Polish business. Moreover, due to the specificity of business related in particular to the presentation of operating business in Poland, its development and constraints imposed by new EU policies being introduced in Poland, the studies on the discussed problem may be carried out with the use of the comparative analysis as well. The comparative analysis may be particularly useful during the studies on the specificity of Polish business and its function within the system in relation to the old and new policies of the EU (Financial Times report, 2012, http://www.eea.europa.eu).

Key research questions include: what is the level of impact exerted upon Polish business by new policies introduced by the EU? Is the introduction of new EU policies significant for the development of business in Poland? Or does it cause its partial destruction that impedes the development of companies, especially smalland medium-sized enterprises, which significantly contribute to the increase and development of GDP in Poland and in most member states of the EU? Is the functioning of business in Poland dependent on new EU policies and new legal regulations introduced by decision-makers at the national level?

\section{Strategic Areas of Business Development in Poland}

For the last two decades, Polish policy of business operations has been implemented at a national level largely on the basis of the aims pursued by the European Union, which influence the modernisation of the state in regards to economic progress, infrastructure development and technological advancement. Such provisions were included, for instance, in the new and last cohesion policy prospect for the period of 2014-2020 and in the priorities of Polish European policy for the period of 2012-2016 (Document of the Polish Ministry of Foreign Affairs, 2012, http://www.msz.gov.pl). The documents focus particularly on matters related to the modernization of the state, which needs to be considered as the correct approach of Polish side in regards to the development of national business in relation to other member states of the EU. Taking into consideration the use of EU means (European funds and EU funds in particular ${ }^{1}$ ), this approach aims to reduce disparities between Western and East-Central Europe, especially between less and better developed regions. This will strengthen the position of Polish business and contribute to its internationalization at European and international levels in regards to the development in various areas (industry, environmental protection, and science, http://www.eba.europa.eu, http://www.eea.europa.eu).

The priorities of business development in Poland are mainly related to the implementation of Polish policy priorities at the European level in the period of 2012-2016, with development perspective for 2030. Considering these priorities, Polish goals include the following areas (Document of the Polish Ministry of Foreign Affairs, 2012, http://www.esma.europa.eu, https://eiopa.europa.eu):

\footnotetext{
${ }^{1}$ European funds are generated not only in the European Union (EU), but also in such countries as Norway, Iceland and Liechtenstein - which are not members of the EU, but belong to the European Economic Area (EEA). EU funds are generated only in the EU member states.
} 
(1) Strong Poland in a strong political union;

Building a competitive, open and secure Union of solidarity, bearing joint responsibility for the future of European integration, while ensuring Poland's interests shall be respected by its other members; constructive participation in the EU decision-making process for the benefit of both Poland on the European scene, and the EU on the global scene.

(2) Poland as a reliable ally in a stable transatlantic order;

Developing one's own deterrence capabilities and maintaining NATO's reliability as a defence alliance; development of EU capabilities with respect to resources and security building measures, independent and complementary to NATO's; participation in mutual confidence building measures between the West and Russia; close cooperation with Ukraine and other countries in Eastern Europe and South Caucasus; combating terrorism and counteracting the proliferation of weapons of mass destruction.

(3) Poland open to different dimensions of regional cooperation;

Cooperation with the West for the sake of security and strong economy; openness and solidarity with the East; reliance on models from the North in the interests of the quality of life of citizens; partnership with the South in pursuing common objectives of civilization; enhancement of cooperation among the Visegrád Group of countries.

(4) Strategy for Poland's development cooperation, promotion of democracy and human rights;

Increase the role of development cooperation in Poland's foreign policy so that this international activity could also contribute to Poland's security and the stability of its neighbors and partners in development cooperation; support for the dissemination of human rights, the rule of law and democracy, in order to create a friendly international environment and to prevent conflicts.

(5) Promoting Poland abroad;

Development of a promotion campaign aimed at enhancing Poland's position in Europe and the world and making it more competitive and attractive for investors and tourists. Development of Polish economy, especially in the area of export.

(6) New quality in relations with Polish diaspora and Poles living abroad;

Implementation of a new Polish diaspora strategy: partnership and cooperation with Polish diaspora and Poles living abroad, leading to understanding and effective support for Poland's raison d'état and Polish foreign policy, and also tapping into the potential of Polish diaspora and Poles living abroad to promote and build a positive image of Poland in the world.

(7) Effective foreign service.

Continued modernization of the Ministry of Foreign Affairs: professional diplomacy, based on the right selection of personnel and the operation of foreign service structures; improvement of coherence and coordination of international initiatives undertaken by the MFA, other government agencies, institutions and non-governmental organisations; modern infrastructure building the image of the state.

\section{Three Dimensions of Business Development in Poland}

The relation between the European policy and Polish aspects and interests is one of the elementary areas for Polish business. Canons of Polish policy at the international level in the period of 2012-2016 take into account Polish businesses operated by particular subjects within the EU. The vision of a united Europe perceived from the perspective of Polish interests was characterized in three key areas: competitiveness, solidarity and openness (Document of the Polish Ministry of Foreign Affairs, 2012, p. 8). 
One of the aspects of the competitiveness is related to the "need to improve the functioning of the eurozone" (Document of the Polish Ministry of Foreign Affairs, 2012, p. 8). The document postulates that Poland will join the eurozone once the eurozone becomes stable. From the perspective of stability of Polish economy and business development in Poland, this element is an important one. Another important matter related to Poland's accession to the eurozone concerns the preparation of Poland from the macroeconomic (macroeconomic conditioning) and legal point of view. It needs to be highlighted that the completion of the internal market (formerly known as the single market) is one of the most important elements that may improve the competitiveness of the EU.

Poland's solidarity within the European policy is related to the priorities aimed at the reduction of disparities between particular regions. Such postulates concern particularly the challenges identified in the Europe 2020 strategy (key strategy of the European Union). The aforementioned postulates aimed at the improvement of competitiveness of Poland in Polish economy and the region include: acquisition of innovative and new technologies, development of modern road, railway, air transport and energy infrastructure (new and modernized), stimulation of municipal investments, for instance in the areas of environmental protection and water management or social infrastructure including matters related to health protection. Creation (continuation) of the Trans-European Transport Network (TEN-T) ${ }^{2}$ within the new prospect for the period of 2014-2020 as well as creation of the European electricity grid within the energy corridors constitutes other important elements related to the development of Polish business. Such an approach and implementation of Polish priority interests has much significance for the creation and maintenance of internal cohesion in the EU, especially in the context of business in Poland, the biggest member state in Central Europe. The aforementioned aspects will also stimulate rapid social and economic development of Poland. Implementation of the aforementioned postulates within the concept of solidarity will take place, for instance, through continuous efforts made to reduce differences in direct payments for farmers working in EU member states, support the pension system at national and European levels, development of raw material base - especially gas and non-conventional oil resources (conventional resources can be extracted in the so-called geological traps formed in porous, permeable rocks covered with an impermeable layer, while non-conventional resources can be found in impermeable, reservoir rocks - bedrock - therefore their extraction is more difficult and expensive. Such resources include, for instance, shale gas). As far as the EU's energy policy is considered, Poland should focus on diversification of actions performed by the Union to increase the level of energy security of particular EU member states, Poland in particular. Taking into account the development of business in Poland, we need to pay close attention to the matters related to climate changes or to the use of such natural resources as coal in such a way to avoid degradation of the natural environment and to allow for the improvement of the economy or job creation with the use of new technologies. Innovative, environmentally friendly solutions are of key importance to environmental protection and help to maintain and create new jobs. "Low-emission Europe" is a

\footnotetext{
2 Trans-European Transport Networks (TEN-T) — an EU programme developed to create a network of transport corridors: road, rail, sea and air routes. It constitutes a part of the Trans-European Networks (TEN). The Trans-European Transport Network Executive Agency (TEN-T EA) is responsible for the implementation of the programme. The Innovation and Networks Executive Agency is responsible for the management of the infrastructure and research projects within the areas of transport, energy and telecommunication. In particular, its actions are focused on the following EU programmes: (1) Connecting Europe Facility (budget: 30 billion euro): transport, energy and digital telecommunication; (2) two areas (budget: seven billion euro) of "Horizon 2020" - the main EU research funding programme; (3) Smart, green and integrated transport ; and (4) Secure, clean and efficient energy. The Innovation and Networks Executive Agency is the successor of the Trans-European Transport Network Executive Agency (TEN-T EA). It started its activities on 1 January 2014.
} 
long-term goal of the EU. It means that in a broader perspective, for instance within the Europe 2020 strategy, EU member states should focus on the improvement of energy efficiency, cogeneration and renewable energy sources (RES). It needs to be emphasized that the aforementioned goals of Poland in the area of energy economics may differ from the goals of other member states of the EU. However, from the Polish perspective, it is important to co-create the EU's approach towards environmental protection and climate change prevention. Due to historical issues, this task seems to be a difficult one, as Polish business and economy largely depend on coal, which is not an entirely ecological resource, but constitutes a cheap source of energy that is easily available on Polish territory.

The concept of openness regards such matters as relations between Poland and its neighboring countries and the enlargement of the European Union. Polish interests involve the development of Polish business together with other member states of the EU or other associated countries through contribution to the political and economic transformation and support for accession aspirations, especially those of Ukraine, Moldova, the states of the Western Balkans, the South Caucasus and Turkey. In order to develop its business, Poland should also focus on the improvement of its security, by involving its "neighbors" in the processes of political, economic and social modernisation, which are also promoted by the EU. The openness is also based on partnership with the third countries through the European External Action Service (EEAS). From the perspective of Polish and EU's interests, the participation of EU member states in the EEAS should be proportional to their populations. Integration of the EU with its neighbors or with candidate countries should be transparent and based on comprehensible and uniform rules. In the context of Polish business, the openness should also involve the relations of Poland with such strategic partners as: Brazil, China, India and Japan. Broadly perceived dialogue with Russia is another important element of the openness. Poland intends to support Russia's modernisation programme, rule of law, political pluralism and freedom of speech.

It needs to be highlighted that Polish business will be conducted through the performance of the following tasks (Document of the Polish Ministry of Foreign Affairs, 2012, p. 13):

(1) Implementation of the "Europe 2020" strategy;

(2) Progress on the path to membership of the euro zone;

(3) Preserving the EU's budget in the 2014-2020 financial perspective with an adequate share allocated to the Cohesion Policy and to the Common Agricultural Policy (for instance reduction of differences in direct payments for farmers);

(4) Completion of the EU's internal market (single market) and support for measures boosting the EU's competitiveness, including the development of a common trade policy, which adequately realises the EU's economic interests in the world by pursuing the principle of reciprocity as the external dimension of a deep internal market;

(5) Creation of an effective common EU energy policy, including the development of a single energy market (currently - internal market), improvement of security of supplies (diversification of supplies), increase in energy efficiency (for instance through cogeneration, RES), shift of emphasis from "low-coal economy" to a "low-emission economy", support for the exploration of non-conventional natural gas and crude oil deposits (e.g. shale gas);

(6) Actions aimed at comprehensive implementation of the already approved decisions on the reduction of the EU's emissions by $20 \%$ by the year 2020 ;

(7) Enhancement of influence on the implementation of the Eastern policy and on the future of the ENP; 
(8) Assurance of uniform standpoint of the EU at G20 meetings, in international organisations and in relations with strategic partners;

(9) Active participation in the EU's actions aimed at the creation of an effective system of migration control, security assurance and prevention against terrorist threats.

\section{Conclusions}

To conclude, the most important areas related to Polish interests realised through the development of business in Poland include: environment, innovations, banking and financial matters, security, energy, fishery, farming and chemical industry. It needs to be emphasized that these areas concern the strict and targeted profile of the state's development through the use of grant possibilities offered, for instance, by the EU's funds in the period of 2014-2020. Simultaneously, they fit into the key areas of policies promoted by the EU. It is difficult to provide a forecast for the development of Polish business in the future. On the one hand, Poland should look after the development of its business and, consequently, focus on Polish interests in the business sector. On the other hand, European institutions were established for the benefit of the EU perceived as a whole. Therefore, the "assignment" of some responsibilities to particular institutions and authorities of the EU involves the realization of the interests of the EU, not particular member states. Nevertheless, business in particular EU states should be looked after. Despite its pessimism, we need to agree with the hypothesis formulated at the beginning of this article. It can be proved, for instance, by the deficit of Polish full-time workers employed in particular EU's institutions to protect, develop and promote business in Poland. Moreover, actions performed in the international forum by the Polish government are not sufficiently coordinated. First of all, Poland should coordinate actions that could function beyond the divisions, regardless of political affiliations or sympathies. Secondly, strategies implemented within particular priorities (areas) should be transparent and have clearly defined goals. Thirdly, actions should not have an ad-hoc character, but they should be performed in a continuous manner. An increase in the amount of workers employed in the EU's institutions, especially Polish experts in particular areas, may be a good solution. Moreover, those Polish goals that are inscribed into European interests (and not always in the interests of Polish business) could be limited. Simultaneously, deliberate and rational lobbying campaigns should be launched. The language barrier, which often makes it impossible to conduct any business negotiations or direct discussions, constitutes a very serious problem. It needs to be emphasized that the increase in the number of workers (experts in particular) could have a significant importance for the development of Polish business and for the improvement of Poland's image in the eyes of international companies as a country with numerous specialists that can be valuable not only due to the low costs of employment, but also due to high added value of their knowledge. Polish business may also be developed through collective cooperation with other countries that have a similar perception of particular topics (areas). Therefore, the conclusion may be rather painful for the development of Polish business, but it will help to increase its expansiveness and methods of operation at a national level, contributing to its internationalization and to the creation of the image of Poland as a strong, substantive partner that looks after its own interests by developing national businesses within the European Union.

\section{References}

Art. 17 ust. 2, Traktat o Unii Europejskiej, Dziennik Urzędowy Unii Europejskiej, C 326 Tom 55, 26 października 2012 (Art. 17 paragraph. 2, the Treaty on European Union, the Official Journal of the European Union, C 326 Volume 55, October 26, 2012).

Czubkowska, S. (March 29, 2015). Polska nie chroni skutecznie swoich interesów w UE. Powód: za mało urzędników w KE, 
Dziennik Gazeta Prawna.

Document produced by the Polish Ministry of Foreign Affairs, adopted in March 2012 by the Council of Ministers, Polish Foreign Policy Priorities 2012-2016. (2012). Warsaw. Retrieved April 27, 2015, from http://www.msz.gov.pl/resource/aa1c4aec-a52f-45a7-96e5-06658e73bb4e:JCR

European Banking Authority, Summary of the EBA, 2011 Annual report, 2012 Annual report, 2013 Annual report (15.06.2015).

Financial Times report. (Oct 2012). Retrieved June 14, 2015, from https://eiopa.europa.eu/about-eiopa/index.html

Retrieved June 14, 2015, from http://www.esma.europa.eu/page/esma-short

Retrieved June 15, 2015, from

http://ftalphaville.ft.com/2012/10/24/1225821/and-now-for-some-basel-3-inspired-deleveraging/?Authorised=false

Retrieved June 1, 2015, from

http://www.kpmg.com/lu/en/issuesandinsights/articlespublications/pages/basel-4-emerging-from-the-mist.aspx

Retrieved June 1, 2014, from http://europa.eu/about-eu/agencies/executive_agencies/inea/index_pl.htm

Retrieved June 14, 2015, from

http://www.eba.europa.eu/about-us;jsessionid=43FBCFAD59CAB71C57CDA3EB1898940B

Retrieved June 15, 2015, from

http://www.eba.europa.eu/documents/10180/601534/EBA2012_online_final2.pdf/9d498bb4-b875-4b25-b8f0-91ac3173b222

Retrieved June 15, 2015, from

http://www.eba.europa.eu/documents/10180/233831/Summary+of+the+EBA+2012+Annual+Report.pdf/5068357b-7544-49

0e-8aa9-2c62518e3225

Retrieved June 15, 2015, from

http://www.eba.europa.eu/documents/10180/699921/Summary+of+the+EBA+2013+Annual+Report.pdf/8ce5375a-1d1e-4ef a-9d9d-08c8bb485ea6

Retrieved May 18, 2015, from

http://www.eea.europa.eu/about-us/governance/management-board/list-of-management-board-members

Retrieved April 27, 2015, from http://www.msz.gov.pl/resource/d31571cf-d24f-4479-af09-c9a46cc85cf6:JCR

Lerche Ch.,O., \& Said, A., A., Jr. (1963). Concepts of international politics. New Jersey: Prentice-Hall.

Nugent, N. (2010). The government and politics of the European Unions (7th ed.). Houndmills, Basingstoke, Hampshire.

Parkinson, C. N. (1958). Parkinson's law: The pursuit of progress. Londyn: John Murray.

Peterson, J., \& Shackleton, M. (2012). The institutiuons of the European Union. Oxford and New York: Oxford University Press.

Rozporządzenie Rady (EWG) nr 1210/90 z dnia 7 maja 1990 r. w sprawie ustanowienia Europejskiej Agencji Środowiska oraz

Europejskiej Sieci Informacji i Obserwacji Środowiska (Council Regulation (EEC) No 1210/90 of 7 May 1990. On the establishment of the European Environment Agency and the European Information and Observation Network Environment), Dz. Urz. WE L 120 z dnia 11 maja 1990 r., str. 1 - 6, Dz. Urz. UE Polskie wydanie specjalne rozdz. 15, t. 1, str. 396-401), http://eur-lex.europa.eu/legal-content/EN/ALL/?uri=CELEX:32009R0401 (24.05.2014).

Rozporządzenie Rady (WE) nr 933/1999 z dnia 29 kwietnia 1999 r. zmieniającym rozporządzenie (EWG), (Council Regulation (EC) No 933/1999 of 29 April 1999. Amending Regulation (EEC).

Rozporządzenie (WE) nr 1641/2003 Parlamentu Europejskiego i Rady z dnia 22 lipca 2003r. zmieniającym rozporządzenie Rady (EWG) $n r$ 1210/90 w sprawie ustanowienia Europejskiej Agencji Środowiska oraz Europejskiej Sieci Informacji i Obserwacji Środowiska (Regulation (EC) No. 1641/2003 of the European Parliament and of the Council of 22 July 2003. amending Council Regulation (EEC) No. 1210/90 on the establishment of the European Environment Agency and the European Information and Observation Network Environment), Dz. Urz. UE L 245 z dnia 29 września 2003 r., str. 1-3; Polskie wydanie specjalne Rozdział 15, Tom 07, 611-613.

Rozporządzenie Parlamentu Europejskiego i Rady (WE) nr 401/2009 z dnia 23 kwietnia 2009r. w sprawie Europejskiej Agencji Środowiska oraz Europejskiej Sieci Informacji i Obserwacji Środowiska-wersja ujednolicona, (Regulation of the European Parliament and Council Regulation (EC) No 401/2009 of 23 April 2009. on the European Environment Agency and the European Network Environment Information and Observation-codified version), Dz. Urz. UE L 126/13 z dnia 21 maja 2009 r.

Tosiek, P. (2007). Komitologia, Szczególny rodzaj decydowania politycznego. Lublin: UMCS. 